\title{
Stem cell hype risks "backlash"
}

Published at www.cmaj.ca on Oct. 8

$\mathrm{H}$ ype about stem cell research being a "driver of economic growth" has inflated expectations and could lead to a backlash, law professor Timothy Caulfield told the 2009 National Health Law Conference in Montréal, Quebec, on Oct. 3.

To protect against this, the message should be moderated and stem cell research should be subject to "good independent governance," argued Caulfield, director of the University of Alberta Health Law Institute in Edmonton.

Economics is increasingly woven into the research infrastructure because of the "overall emerging idea" that research is about economic growth, not about investigation and discovery, said Caulfield.

Stem cell research is a key example of this trend, and this has "put a lot of pressure on researchers." Around the world, jurisdictions are producing documents to promote potential economic spinoffs and setting "specific metrics than can be measured," he told an audience of about 200, which consisted mostly of legal professionals.

For example, in the United States, an economic impact document predicts this research will create 230000 jobs and US\$88 billion in economic activity in Texas.

And Qatar, which last spring hosted the First International Stem Cell Workshop in Doha, has invested billions into this research on the premise that it will replace oil to become the "future economic engine" of the country.

Caulfield said that of the many documents he has reviewed, only Proposition 71 , the bond for state-supported stem cell research approved by Californians in 2004, mentions a potential downside to the research: potential complications from intellectual property laws.

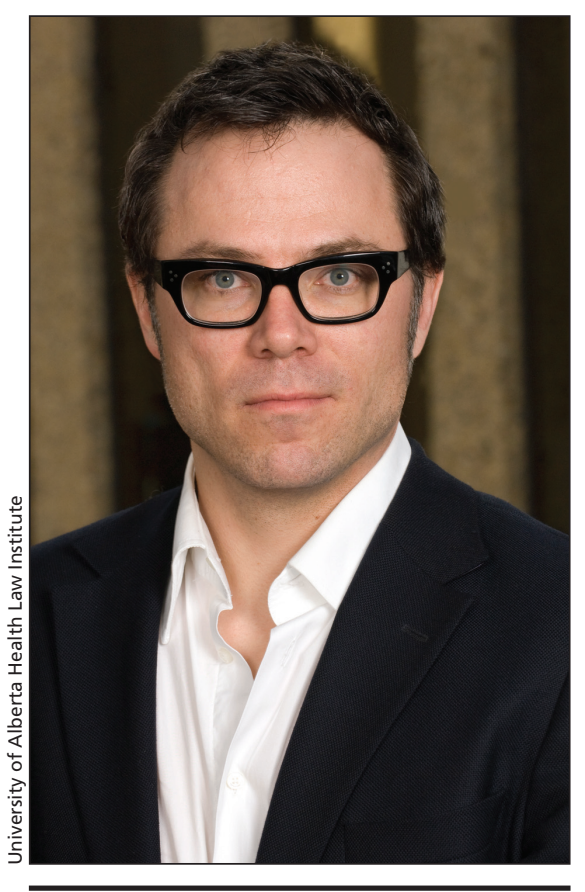

There are a lot of "elephants in the room" regarding stem cell research, including the time frame in which therapies might ultimately emerge, says Timothy Caulfield, director of the University of Alberta Health Law Institute in Edmonton.

But unanswered questions, which Caulfield labelled the "elephants in the room," include:

- Will therapies materialize? Caulfield, who classifies himself as a "believer," acknowledged that huge scientific hurdles remain. He noted that the former head of the international stem cell network put the time frame for the research to produce results at 50-100 years. The research is "not a recipe for rapid economic growth," he said.

- Can the research be commercialized? Cells are supposedly designed for individuals, so "where are the big products?" Caulfield asked. As well, the cells would be deemed health products that require time- consuming federal regulatory approval, and some critics argue that health care systems aren't structured to allow the introduction of the individualized regenerative medicine promised by the research.

- Will public trust be eroded? Trust is at risk if the promised health and economic benefits fail to materialize, Caulfield said. Already controversial on moral grounds, stem cell research has emerged in an era of commercialization, and some studies show that public trust is weaker when private industry is involved in publicly funded research, he noted. As well, premature implementation of stem cell research could put the enterprise at risk. Already, clinics such as Beike Biotechnology Co. Ltd. of Shenzen, China, say they have used stem cells to successfully treat a range of diseases, he added. But no data has been made public.

Caulfield told conference participants that some scholars have argued the need for an organization to monitor commercialization for its impact on the public good. If the commercialization agenda is accepted, processes should be developed to prevent developments such as premature implementation, said Caulfield, a theme leader for the Stem Cell Network (one of the National Centres of Excellence) and editor of the Health Law Journal.

However, he added that he is becoming skeptical of the need for the stem cell oversight committee of the Canadian Institutes of Health Research, especially since "only two or three researchers in Canada, or maybe none now" are doing research using embryonic stem cells. "Social issues and concerns could be dealt with other ways." — Ann Silversides, CMAJ

DOI:10.1503/cmaj.109-3074 